\title{
Knowledge, Attitude and Perception of Undergraduate Medical Students Regarding Community Based Research
}

K. VANI PRIYANKA*1, K. VANI MADHAVI ${ }^{2}$

INTRODUCTION: Research environment in developing countries including India is witnessing a slow but positive rise.

AIM: To assess the knowledge, attitude and perception of medical students regarding the community based research.

MATERIALS AND METHOD: The study employed a cross-sectional., community based research in Konaseema Institute of Medical Sciences (KIMS), Amalapuram and included a sample of 115 undergraduate students in the $3^{\text {rd }}$ semester. Data was collected through a semi structured questionnaire and pilot testing was done and the questionnaire was finalised. The questionnaire tested the knowledge, attitude and perception regarding the community oriented research of the undergraduate students. Statistical analysis was done using Epi-info statistical software package version $3.5 \cdot 4$

RESULTS: Majority (84.34\%) of the study participants were in the age group of $\mathbf{2 0 - 2 1}$ years of which $59.13 \%$ were females. Majority (82.6\%) of them have good knowledge regarding steps in planning the research, and also regarding the study design, sample size calculation and graphical representation of data. Most of the students (53.9\%) of them expressed epidemiology to be a very interesting subject and $66.1 \%$ of the students felt that community oriented research was interesting

CONCLUSION: Community oriented research should be introduced early in the teaching curriculum to teach research methodology to undergraduate medical students and to instil confidence among them to work as independent researchers in the future

KEYWORDS: Community Based Research, Undergraduate students, Epidemiology

\section{INTRODUCTION}

Research is a critical component in progress and prosperity of institution and nations. The research environment in developing countries including India is witnessing a slow but positive rise. ${ }^{1}$

Health research has an impact on health policy. It plays a crucial role in medical development. ${ }^{2}$ Medical research is mandatory at post-graduate level and Medical Council of India (MCI) in its amendments has suggested increasing exposure of theoretical and experiential project-based research at undergraduate level. It also envisages that on completion of the course in Community Medicine subject, the student should be able to use epidemiology as a scientific tool to make rational decisions relevant to the community and to collect, analyse, interpret and present community based data.

It inculcates critical thinking and reasoning skills and develops a positive attitude towards scientific research. ${ }^{3,4,5}$

Aim: To assess the knowledge, attitude and perception of medical students regarding the community based research.

\section{MATERIAL AND METHODS}

Study Design: Cross sectional study.

Setting: Konaseema Institute of Medical Sciences (KIMS), Amalapuram.

Study Population: Undergraduate students who were in the $3^{\text {rd }}$ semester.

Sample Size: 115 students among them 47 were male and 68 were female.

Data Collection Procedure: In our college undergraduate students are doing a research project in their community medicine posting, for that we have briefed all the $3^{\text {rd }}$ semester students regarding the research methodology. The students were then asked to come up with a research question and subsequently they have done the research in the our catchment area under the supervision of a faculty incharge.

The authors developed a semi structured questionnaire and pilot testing was done and finalised the questionnaire. With that questionnaire we have tested their knowledge, attitude and perception regarding the community oriented research.

Statistical Analysis: Epi-info statistical software 
package version 3.5.4 was used for data analysis.

Ethical Consideration: Institutional ethics committee (IEC) approval was taken, informed written consent was obtained from the participants.

\section{RESULTS AND DISCUSSION}

Majority $(84.34 \%)$ of the study participants were in the age group of 20-21years and 59.13\% were females. Knowledge gained was satisfactory. Majority (82.6\%) of them have good knowledge regarding steps in planning the research, and also regarding the study design, sample size calculation and graphical representation of data. But they have to improve their knowledge regarding the types of variables and analysis of data and related software. (Table -1)

Research skills and critical review of scientific literature should start early in the career of a health professional and it should be in a life long learning process. Lack of interest and lack of education system in imparting training to students regarding research skills and considering it as useless activity was one of the prime reasons for students disinterest towards

\begin{tabular}{|c|c|c|c|}
\hline $\begin{array}{l}\text { Knowledge regarding } \\
\text { various aspects of the } \\
\text { research }\end{array}$ & $\begin{array}{c}\text { SATISFACTORY } \\
\text { n }(\%)\end{array}$ & $\begin{array}{l}\text { FAIR } \\
\text { n (\%) }\end{array}$ & $\begin{array}{l}\text { POOR } \\
\text { n }(\%)\end{array}$ \\
\hline $\begin{array}{c}\text { Steps in planning the } \\
\text { research }\end{array}$ & $95(82.6)$ & $12(10.4)$ & $8(7.0)$ \\
\hline Study instruments & $68(59.1)$ & $5(4 \cdot 3)$ & $42(36.6)$ \\
\hline Study design & $82(71.3)$ & $7(6.1)$ & $26(22.6)$ \\
\hline Sample size calculation & $98(85.2)$ & o & $17(14.8)$ \\
\hline Types of variables & $28(24 \cdot 3)$ & $2(1.7)$ & $85(74.0)$ \\
\hline $\begin{array}{c}\text { Graphical } \\
\text { representation of Data }\end{array}$ & $96(83.5)$ & $4(3 \cdot 5)$ & $15(13.0)$ \\
\hline Search engines & $59(51.3)$ & $24(20.9)$ & $32(27.8)$ \\
\hline Analysis of data & $7(6.1)$ & $59(51.3)$ & $49(42.6)$ \\
\hline
\end{tabular}

Table 1. Knowledge Regarding the Research Methodology among Students

research. $^{6}$

In this study for measuring the attitude and perception of students regarding community based research Likert scale was found appropriate because of its relative ease and straightforward interpretation of results.

Majority(66.1\%) of the students felt that community oriented research was interesting and $60 \%$ of the students agree that engaging students in mentored community oriented research will help to develop research skills.(Table 2)

Majority (53.9\%) of them expressed epidemiology to be a very interesting subject. Epidemiology and survey methodology were considered as most useful for critical review, literature search and medical writing. In a study conducted in Puducherry $90 \%$ of the students perceived epidemiology based community block postings as highly useful particularly with regards to the survey per se. ${ }^{7}$
$60.1 \%$ of the students felt that training courses and workshops on community oriented survey methodology should be integrated in the medical curriculum. In a study from Pakistan reported that faculty of medical school perceived research methodologies to be learnt better by community oriented medical education as compared to conventional lectures. ${ }^{8}$

\section{CONCLUSION}

Most of the students have good knowledge and positive attitude towards community oriented research and majority perceived them as useful. It should be introduced early in the teaching curriculum to teach research methodology to undergraduate medical students and to instil confidence among them to work as independent researchers in the future. Critical thinking, creation of a hypothesis, experimentation and teamwork are all abilities needed in every day clinical practice that can be acquired while doing a research project. 


\begin{tabular}{|c|c|c|c|c|c|}
\hline Statements & Strongly agree & Agree & $\begin{array}{c}\text { Neither Agree } \\
\text { nor Disagree }\end{array}$ & Disagree & $\begin{array}{l}\text { Strongly } \\
\text { Disagree }\end{array}$ \\
\hline $\begin{array}{l}\text { I found community-oriented } \\
\text { research was interesting }\end{array}$ & $19(16.5)$ & $76(66.1)$ & $20(17.4)$ & o & o \\
\hline $\begin{array}{c}\text { Community based research is } \\
\text { more exciting than hospital- } \\
\text { based research }\end{array}$ & $14(12.2)$ & $39(34.0)$ & $28(24 \cdot 3)$ & $29(25.2)$ & $5(4 \cdot 3)$ \\
\hline $\begin{array}{l}\text { Engaging MBBS students more } \\
\text { in mentored community- } \\
\text { oriented research projects will } \\
\text { help to develop research skills }\end{array}$ & $41(35 \cdot 7)$ & $69(60.0)$ & $3(2.6)$ & $2(1.7)$ & o \\
\hline $\begin{array}{l}\text { Community-oriented research } \\
\text { will help in my future as a } \\
\text { physician }\end{array}$ & $32(27.8)$ & $56(48.7)$ & $22(19.1)$ & $4(3 \cdot 5)$ & $1(0.9)$ \\
\hline $\begin{array}{l}\text { Training courses and } \\
\text { workshops on community- } \\
\text { oriented survey methodology } \\
\text { should be integrated in the } \\
\text { medical curriculum }\end{array}$ & $25(21.7)$ & $70(60.1)$ & $14(12.2)$ & $6(5.2)$ & o \\
\hline $\begin{array}{l}\text { I found epidemiology to be a } \\
\text { very interesting subject }\end{array}$ & $15(13.0)$ & $62(53.9)$ & $30(26.1)$ & $8(7.0)$ & o \\
\hline $\begin{array}{l}\text { I am confident of conducting a } \\
\text { research project in the } \\
\text { community on my own }\end{array}$ & $3(2.6)$ & $48(41.7)$ & $48(41.7)$ & $14(12.2)$ & $2(1.7)$ \\
\hline
\end{tabular}

Table 2. Attitude and Perception of Students Regarding Community-Oriented Research

\section{REFERENCES}

1. Sachdeva S, Neha Taneja, Nidhi Dwivedi. Knowledge, attitude and practices studies conductedamongst medical students of India. Int J Community Med Public Health. 2018;5(9):3913-8. 2. Khobragade S, Khobragade Y, Lutfi Abbas A B. A study on knowledge, attitude and approach towards research methodology amongst Malaysian medical students. MJMS. 2018;3(1):6-11. 3. Mitwalli HA, Al Gamdi KM, Moissa NA. Perceptions, attitudes and practices among resident physicians in training in Saudi Arabia. WHO EMRO. 2014;20(2): 1-9.
4. Bjorkstrom ME, Johanson IS, Hamrin EKF, Athlin EE. Swedish nursing students' attitudes to and awareness of research and development within nursing. J Advance Nursing. 2003;41(4):393402.

5. Memarpour M, Fard A P, Ghasemi R. Evaluation of attitude to, knowledge of and barriers toward research among medical science students. Asia Pacific Family medicine. 2015; 14:1.

6. AFS Sheikh SA, Kaleem A, Waqas A.Factors contributing to lack of interest in research among medical students. Adv Med Educ Pract.2013;4:23743. 
7. Soudarssanane MB, Sahai A. Innovative field training in epidemiology, Indian $\mathrm{J}$ Community Med 2007;32(1):86-7.
8. Khan I, Fareed A.Perceptions of students and faculty about conventional learning and community oriented medical education J Coll physians Surg Pak.2003;13(2):82-5.

Source of support: Nil, Conflict of interest: None declared

Cite this article as:

Priyanka KV, Madhavi KV. Cardiovascular Disease Risk among Rural Population

of South India. Int Healthc Res J. 2019;3(1):44-47. doi: 10.26440/IHRJ/0301.04.521074

\section{AUTHOR AFFILIATIONS:}

1. Final Year PG, KIMS, Amalapuram, East Godavari District, Andhra Pradesh (Corresponding Author)

2. Professor \& HOD, Department of Community Medicine, KIMS, Amalapuram, East Godavari District, Andhra Pradesh.

For article enquiry/author contact details, e-mail at: editor.ihrj@gmail.com,editor@ihrjournal.com 